\section{CHEMICAL ENGINEERING EDUCATION}

$\mathrm{T}$

HE symposium on chemical engineering education held at the University of Birmingham during April 9-11 should, as Mr. J. A. Oriel pointed out, be regarded as a domestic sequel to the conference sponsored by the Organization for European Economic Co-operation held in London in 1953. The symposium was arranged in four sessions covering the requirements of industry, methods of training, new trends in teaching, and recruitment to the profession.

After a welcome to the University and in particular to the new chemical engineering buildings by Prof. F. H. Garner, the first session was opened by Dr. D. Clayton (Imperial Chemical Industries), who spoke of the demands of the chemical industry. He explained that the new graduate may be employed in research, design or operation of plant and will receive training in all these spheres during his early years with a company. For this and other reasons, Dr. Clayton voiced the view generally sup. ported by others, and certainly by the educational members at the symposium, that universities should concentrate on fundamentals. The additional technological training required can best be obtained 'on the job', provided that the graduate is already well grounded in basic sciences. In discussing postgraduate work, he felt more use should be made of the M.Sc. degree, as this gives a man an insight into research which is adequate for the majority. $\mathrm{He}$ explained that the chemical industry employs people with various forms and level of training, and that it is most important to have an adequate number of assistants if the maximum use is to be made of the best honours graduate. Prof. K. G. Denbigh later made reference to the lack in Britain, as compared with North America, of a large body of men trained just below honours standard.

Dr. F. Mayo (Esso) gave a clear indication of the urgent need for more chemical engineers when he stated that, of its combined intake of scientists and technologists, his company would like some 50 per cent to be chemical engineers, whereas it was only getting some 20 per cent. While welcoming the Government's new plans for technical education, he would press not only for thoir speedy implementation, but also for further consideration as to whether they are in fact adequate. Dr. Mayo stressed that the ideal process engineer needs imagination and an appreciation of the way in which another man's work influences his own. This can be achieved by movement of the young graduate through various departments, such as plant technical service, plant economics, process design and plant operation. It was his view that men trained in chemical engineering were much more flexible and easier to rotate than those trained in pure science. This is one of the reasons why men with this training are in such demand. He reiterated the point that the university graduate fails mainly in his lack of ability at writing reports and suggested that it takes his company about two years to correct this. He also thought that the American graduate settles down to active work rather more quickly than the British.

Mr. A. S. White (U.K. Atomic Energy Authority) explained the needs of the various Government departments with particular reference to the atomic energy establishments, which employ the greatest number of chemical engineers. In the research departments the main need is for good honours graduates, many of whom should have taken a research degree. There is a smaller need for the plant-manager type but an urgent need for design engineers. Here Mr. White put in a plea for more men with mechanical engineering training, such as might be obtained through a graduate apprenticeship. The experimental officer class provides a good opening for those who do not take honours degree courses.

'The requirements of the chemical plant industry were put by Mr. J. P. V. Woollam and Mr. J. D. MeFarlane (Simon Carves), who described the execution of a typical contract through the design, construction and commissioning stages, and they then outlined the qualities required by men taking up this type of work. They would like to see more graduates with a sense of cost consciousness, and they suggested that in the vacation the undergraduate should seek experience of general heavy engineering.

In opening the discussion, Sir Harold Hartley indicated the wide range of activities of the chemical engineer and his place in the optimizing of flow sheets. Chemical engineers by training are suited to making the right compromise in design. He felt that Dr. Clayton and Dr. Mayo rather under-rated the importance of research, because it is vital to have men coming forward who know where research can help. Dr. E. H. T. Hoblyn felt that the chemical engineer must do more on design, and that he was well fitted by wide training to be a project co-ordinator. He did not think that young engineers should become too divorced from plant itself and he regarded design problems as valuable in this respect. Prof. F. Morton went straight to the heart of the problem of the supply of teachers. If industry really wants more chemical engineers then it must make greater contributions to the universities. The lending of a few men to the universities to act as temporary academic staff for the next few critical years would make an enormous difference to the rate of growth, particularly of the newer departments in this subject. It would, he argued, be a good investment by industry.

\section{Methods of Training}

It is now clear that the majority of new graduates will have taken the undergraduate course, usually of three years. In discussing this type of course, Prof. F. H. Garner explained that, as the chemical engineer is primarily concerned with process industries, he should be trained to appreciate process design and plant efficiencies. On the operational side he must be introduced to efficiency of production and shown that this is effected by considerations of utilities, yields, human relations, and reliability of plant, as much as by pure technical calculations. The young chemical engineer must be trained to make decisions based on physical and chemical relationships, but he must learn that these relationships often have to be extended beyond their precisely known limits in order to solve problems in the time available. In that the chemical engineer would have to work with scientists of widely different training, he suggested that it is preferable for him to learn chemistry with the chemists; but in the discussion some members thought that more of the training should be in the hands of the chemical engineering department. The design problem he regarded as particularly suited for 
tutorial instruction and it also provides an opportunity for the student to correlate much of his learning.

The development of the postgraduate diploma course was discussed by Prof. M. B. Donald (University College, London). This course had been formed by a marriage between chemistry and engineering, but the engineering content had been small. Of those taking these courses, some 95 per cent had previously studied chemistry, and there is little doubt that training in physical chemistry forms a valuable introduction to many features of chemical engineering. Mechanical engineers have a more difficult road in this respect. The main problem to-day is that the content of chemical engineering has been so extensively expanded that it is difficult to fit diploma candidates into the final year of the undergraduate course. There are special advantages in these courses for those who have been for a year or two in industry.

The position of the subject in technical colleges was given by Dr. P. F'. R. Venables (Birmingham College of Technology). The number of candidates taking part-tim, courses is small, but the percentage of successful candidates has been high. There are eight colleges running these courses, but the response from industry has been small. Dr. Venables thought that the newer sandwich courses were more suitable for chemical engineering. The advantages of obtaining first-hand experience of industry at the same time as taking an academic course seem considerable in this subject. The total content of knowledge demanded by modern professional qualifications made it increasingly difficult for a man to train for these qualifications on a part-time basis. The part-time system is no longer adequate for educating modern technologists as distinet from providing a minimum training for them.

Mr. G. U. Hopton (North Thames Gas Board) explained the many difficulties of the lone man studying by private study. Such candidates for the examina. tion for associateship of the Institution of Chemical Engineers should have trained in chemistry or in engineering by formal study before starting private study in chemical engineering. It is also essential for a man to be engaged in work of a chemical engineering nature.

\section{New Trends in Teaching}

Prof. E. S. Seller's (Swansea) explained the importance of mathematics as a tool in design, whether in analysis or in synthesis. Physical design, including the optimization of variables, cannot be done successfully without mathematical tools, and the teaching of mathematics must therefore be associated with its physical and chemical applications. He outlined a three-year course, the main feature of which was the integration of mathematics with chemical engineering in the last year, when the application of mathematics would be given by the chemical engineering depart. ment mainly in the form of problems.

Thermodynamics was indicated by Prof. K. G. Denbigh (Edinburgh) as one of the basic studies of chemical engineers. He suggested that a generous provision should be made for this work, both because of its utility and also because of its educational value. It was important to give a real discussion of fundamentals, as the natural inclination of engineering students was to concentrate on the application of a tool. He indicated the application of thermodynamics in several parts of the subject, including its less generally realized use in the calculation of manufacturing processes.

Dr. F. Rumford described the practical training scheme run by the Royal College of Science and Technology, Glasgow. There is no doubt that practical training on industrial units for a short period forms an ideal complement to the theoretical training of the lecture rooms. Realization of some of the difficulties with large units assists the beginner in forming an opinion of the merits and limitations of theoretical work. It must be remembered that these courses do not, and cannot, provide real training in plant operation, and the industrialists must be pre. pared to provide extended practical training for all graduates. 'This is on $\theta$ of the difficulties facing small firms, but there can be no doubt that careful training schemes will bring out the best in the new recruit. Plant manufacturers are equally involved in this problem.

Prof. J. M. Coulson (Durham) traced the changing attitude to unit operations, which had been the basis of the initial courses in this subject. The main change in the past fifteen years had been in the co-ordination of these operations and their reclassification as aspects of heat transfer, mass transfer and momentum transfer. In so doing we had created chemical engineering science, in which the study of the basic mechanisms of interphase transfer was predominant. With regard to the future, he suggested that it would be wrong to regard chemical engineering science as synonymous with chemical engineering. He put in a plea for encouragement of the inventive mind, particularly with regard to new forms of equipment. Men leaving British educational establishments should not only have a feeling for cost consciousness but also a sense of urgency.

\section{Opportunities and Recruitment}

The third session, on recruitment to the profession, was opened by Mr. A. A. Part (under-secretary, Ministry of Education), who, in speaking of the technological awakening, indicated the brighter prospects for technological training. He warned the conference that the opportunities for chemical engineers must be brought home much more strongly to school-boys and their parents. A strong and up-to-date pattern of courses must be developed which must receive determined support from industry. Mr. Part mentioned that the so-called "post-war bulge' will increase the numbers in the eighteen-year. old group, from the present figure of 640,000 , to 850,000 in 1965 . The increasing tendency, 5 per cent per annum, for boys and girls to stay at school until the age of eighteen will further increase the number of potential university and technical college students. With regard to quality, he noted that 51 per cent of the State scholarship winners of 1955 were going to road science or technology. The schools had moved over to science, but the need now is for a move to technology. He was particularly anxious that the profession should make a clear statement regarding its demands for space in the technical colleges, as preparations must be started at once.

Mr. R. Groves (High Master of Dulwich) gave a most interesting account of science-training in British schools, emphasizing that science is now firmly estab. lished as a desirable course. The aim is to produce cultured young people who are educated as well as trained in vocational subjects. In the sixth form all should be devoting some time to writing English and to 
studying a foreign language. He asked industrial members whether they could not do more for the science masters at the schools, perhaps by providing some possibilities for research, but certainly by showing a real interest in them. He took the opportunity of thanking industry for making so marked a contribution to the problem of laboratories in the independent schools.

Mr. J. A. Oriel (president of the Institution of Chemical Engineers) maintained that the opportunities for chemical engineers are excellent and that the profession is showing a most vigorous growth. He claimed that Britain needs at least five times as many chemical engineer's leaving the various educational establishments as at present, and that the opportunities for new recruits are excellent. The process industries throughout the world are experiencing a period of outstanding growth, and central to their progress lies the chemical engineer. Referring to the petroleum industry, Mr. Oriel instanced the developments in the past thirty-five years, but he believed there was an even brighter fu ure ahead. In Britain, chemical engineers are almost equally divided between research, development, construction and operation. In North America, with its longer period of development in this field, chemical engineers are in administration in a greater proportion than ehemists or other engineers.

In reviewing the symposium, Prof. D. M. Newitt (Imperial College of Science and Tec..nology) thought that industrialists were right in placing emphasis on character development rather than on functional efficiency, but he maintained that a period of postgraduate studies was of greater value than indicated by the industrial members. He thought that we should probably change the nature of our training even more rapidly. Present syllabuses tend to be a legacy of the past and could with advantage be given a new look. Chemical engineering science could conveniently be regarded as a link between physical sciences and technology, and he gave a brief outline of proposals on these lines, in which the traditional studies of mechanical and electrical engineers were merged into chemical engineering science.

J. M. Coulson

\section{WOMEN IN INDUSTRY}

$\mathrm{W}$ HEN the history of the twentieth century is written, the year 1957 will surely be noted, inter alia, as the one when women really began to press their claims for equal career opportunities with men. Their efforts to secure equal social rights through equal educational opportunities has met with considerable success, and, within a few years, they should achieve equal material rewards for equal work. In many activities, and especially in the professions, they have reached positions of eminence and fow doors still remain closed to them. In one sphere, however, they have made little progress. This, of course, is the world of industry, and during the past few months the voice of woman has been raised in many parts of the world protesting against the domination of man in industrial and commercial activities. In Britain that voice has been heard at various conferences and courses, while powerful arguments for career emancipation have been propounded in all kinds of journals.

It was appropriate, therefore, for the British Federation of University Women to form a working party to examine all the opportunities open to girls and women with qualifications in science and technology. Its report* has now been published and contains details of jobs available to girls and women in industry, the professions, agriculture and the Armed Forces. The compendium has been painstakingly prepared, and, in the section dealing with openings in the professions and Armed Forces, will be invaluable to headmistresses and university authorities, parents and girls in their formative years; details of jobs are accompanied by details of qualifications neoded to fill them.

In the sections concerned with opportunities in industry, however-and these are very few in a report of this size-the working party has been less than fair to members of their own sex who wish to take up work in industry. Perhaps it was unfortunate that only one of the working party of twenty-four women appears to have had definite experience in industry and that in a specialist job.

If the working party had included one or two women members with experience of management in industry - the managing director of Boxfoldia would have been an excellent choice-more attention might have been paid to the very real difficulties confronting a girl who is keen on an industrial career. Although there is still considerable male prejudice against the employment of able women in industry, not all men are prejudiced; there are real difficulties and these must be squarely faced if they are to be overcome.

First, women, like men, would have to see that, although it has other functions, industry must make profits or it would cease to be. The comparative security of the past twenty years has led to great emphasis on the 'service' aspects of industry. 'This is surely right and cannot be over-stressed. But manufacturing industry can never be a service in the same sense as a profession like medicine, and the competitive element cannot be eliminated. Aspiring women, therefore, should be clearly told that, while industry overall has a social purpose, many industrial firms fail every day and many more are likely to do so. They should accept, too, that industry has not settled patterns of promotion like many professions and the Armed Services and that, even to-day, many men in senior positions have little formal education or training; the secrets of success in industry are still far from clear.

It should also be made clear that many of the openings in industry described in the report will lead to important specialist positions in industry but not to senior positions; the latter will still go to those who are able to co-ordinate the work of the specialist. It is surprising that a report of this kind could be prepared without including the word 'management'; that appears to be the case. Women graduates, too, should be warned that in many industrial organizations which employ male graduates, the latter are finding it difficult to make headway against traditional rule-of-thumb methods of management.

'The real difficulty, however, which must be overcome before women are accepted in senior positions in industry is the question of marriage and childbearing. These topics are not mentioned in the report. Yet if a manufacturer is faced with two people for a key appointment, he is unlikely to provide expensive training for one on whom the odds of leaving are much greater than the other. It is little use telling him that this training will not be lost to

* Opportunities for Girls and Women in Science and Technology. 2s. net. 